\title{
Front Matter: Volume 7414
}

, "Front Matter: Volume 7414," Proc. SPIE 7414, Liquid Crystals XIII, 741401 (15 September 2009); doi: 10.1117/12.846114

Event: SPIE Photonic Devices + Applications, 2009, San Diego, California, SPIE. United States 


\section{PROCEEDINGS OF SPIE}

\section{Liquid Crystals XIII}

lam Choon Khoo

Editor

2-5 August 2009

San Diego, California, United States

Sponsored and Published by

SPIE

Volume 7414

Proceedings of SPIE, 0277-786X, v. 7414

SPIE is an international society advancing an interdisciplinary approach to the science and application of light. 
The papers included in this volume were part of the technical conference cited on the cover and title page. Papers were selected and subject to review by the editors and conference program committee. Some conference presentations may not be available for publication. The papers published in these proceedings reflect the work and thoughts of the authors and are published herein as submitted. The publisher is not responsible for the validity of the information or for any outcomes resulting from reliance thereon.

Please use the following format to cite material from this book:

Author(s), "Title of Paper," in Liquid Crystals XIII, edited by lam Choon Khoo, Proceedings of SPIE Vol. 7414 (SPIE, Bellingham, WA, 2009) Article CID Number.

ISSN 0277-786X

ISBN 9780819477040

Published by

SPIE

P.O. Box 10, Bellingham, Washington 98227-0010 USA

Telephone +1 3606763290 (Pacific Time) · Fax +1 3606471445

SPIE.org

Copyright (C) 2009, Society of Photo-Optical Instrumentation Engineers

Copying of material in this book for internal or personal use, or for the internal or personal use of specific clients, beyond the fair use provisions granted by the U.S. Copyright Law is authorized by SPIE subject to payment of copying fees. The Transactional Reporting Service base fee for this volume is $\$ 18.00$ per article (or portion thereof), which should be paid directly to the Copyright Clearance Center (CCC), 222 Rosewood Drive, Danvers, MA 01923. Payment may also be made electronically through CCC Online at copyright.com. Other copying for republication, resale, advertising or promotion, or any form of systematic or multiple reproduction of any material in this book is prohibited except with permission in writing from the publisher. The CCC fee code is 0277-786X/09/\$18.00.

Printed in the United States of America.

Publication of record for individual papers is online in the SPIE Digital Library.

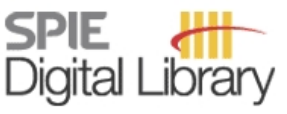

SPIEDigitalLibrary.org

Paper Numbering: Proceedings of SPIE follow an e-First publication model, with papers published first online and then in print and on CD-ROM. Papers are published as they are submitted and meet publication criteria. A unique, consistent, permanent citation identifier (CID) number is assigned to each article at the time of the first publication. Utilization of CIDs allows articles to be fully citable as soon they are published online, and connects the same identifier to all online, print, and electronic versions of the publication. SPIE uses a six-digit CID article numbering system in which:

- The first four digits correspond to the SPIE volume number.

- The last two digits indicate publication order within the volume using a Base 36 numbering system employing both numerals and letters. These two-number sets start with 00, 01, 02, 03, 04 , $05,06,07,08,09,0 A, 0 B \ldots$. OZ, followed by 10-1Z, 20-2Z, etc.

The CID number appears on each page of the manuscript. The complete citation is used on the first page, and an abbreviated version on subsequent pages. Numbers in the index correspond to the last two digits of the six-digit CID number. 


\title{
Contents
}

\author{
$\checkmark \quad$ Conference Committee \\ vii WISE: the Wide-field Infrared Survey Explorer (Plenary Paper) [7419A-204] \\ E. L. Wright, Univ. of California, Los Angeles (United States)
}

\section{SESSION 1 NOVEL LIQUID CRYSTALLINE OPTICAL MATERIALS}

741402 Red-green-blue 2 D tuneable liquid crystal laser devices (Invited Paper) [7414-01]

H. J. Coles, S. M. Morris, A. D. Ford, P. J. W. Hands, T. D. Wilkinson, Univ. of Cambridge (United Kingdom)

$741404 \quad$ Molecular design of main-chain liquid crystalline polyolefin (Invited Paper) [7414-03] N. Naga, Shibaura Institute of Technology (Japan); M. Sone, Tokyo Institute of Technology (Japan); K. Noguchi, S. Murase, Tokyo Univ. of Agriculture and Technology (Japan)

$741407 \quad$ Electro-optical effects of oxidized multi-walled carbon nanotube doping on holographic polymer dispersed liquid crystal films [7414-06]

S. K. Shriyan, A. K. Fontecchio, Drexel Univ. (United States)

\section{SESSION 2 LIQUID CRYSTAL LASERS: IMAGING AND TUNING DEVICES}

$741408 \quad$ Microscopic birefringence imaging by phase-shift interferometry using a liquid crystal phase shiffer (Invited Paper) [7414-07]

T. Nose, Y. Terui, M. Mizumoto, K. Okano, H. Muraguchi, N. Ozaki, R. Ito, M. Honma, Akita Prefectural Univ. (Japan)

\section{SESSION 3 OPTICAL TUNING AND SWITCHING: MICROWAVE APPLICATION}

7414 OD New wavelength-tuning method in optical ring resonators with liquid crystal cladding: exploiting the longitudinal E-field [7414-12]

W. De Cort, J. Beeckman, Univ. Gent (Belgium); R. James, F. A. Fernandez, Univ. College London (United Kingdom); R. Baets, K. Neyts, Univ. Gent (Belgium)

7414 OE Dynamic control of liquid-crystalline helical structures with the aid of light- and temperature-driven multi-stable chiral materials (Invited Paper) [7414-13] M. Kawamoto, N. Shiga, T. Aoki, T. Wada, The Institute of Physical and Chemical Research (Japan)

$7414 \mathrm{OH} \quad$ Photoswitchable gas permeation membranes based on azobenzene-doped liquid crystals (Invited Paper) [7414-16]

E. Glowacki, K. L. Marshall, C. W. Tang, Univ. of Rochester (United States) 
7414 OK Non-linear light propagation and bistability in nematic liquid crystals (Invited Paper) [7414-19]

J. Beeckman, K. Neyts, W. De Cort, A. Madani, Univ. Gent (Belgium)

7414 OL Azobenzene liquid crystals for fast reversible optical switching and enhanced sensitivity for visible wavelengths (Invited Paper) [7414-20]

U. Hrozhyk, S. Serak, N. Tabiryan, BEAM Engineering for Advanced Measurements Co. (United States); D. M. Steeves, L. Hoke, B. R. Kimball, U.S. Army Soldier Systems Ctr. (United States)

\section{SESSION 5 OPTICAL SWITCHING, OPTOELECTRONIC DEVICES, OPTICAL MANIPULATION}

$74140 \mathrm{M} \quad$ Colloidal structures and interactions in a nematic liquid crystal (Invited Paper) [7414-21] M. Škarabot, J. Stefan Institute (Slovenia) and Univ. of Ljubljana (Slovenia); M. Ravnik, Univ. of Ljubljana (Slovenia); U. Tkalec, M. Humar, J. Stefan Institute (Slovenia); S. Žumer, J. Stefan Institute (Slovenia) and Univ. of Ljubljana (Slovenia); A. Nych, U. Ognysta, V. Nazarenko, Institute of Physics (Ukraine); I. Muševič, J. Stefan Institute (Slovenia) and Univ. of Ljubljana (Slovenia)

741400 Fabrications of liquid-crystal polarization converters and their applications (Invited Paper) [7414-37]

S.-W. Ko, S.-H. Huang, A. Y.-G. Fuh, National Cheng Kung Univ. (Taiwan); T.-H. Lin, National Sun Yat-Sen Univ. (Taiwan)

\section{SESSION 6 WAVE MIXING, SLOW LIGHT, HOLOGRAPHIC DEVICES, NANOMACHINE}

7414 OR Two-wave mixing and slow-light effects in liquid crystal light-valves (Invited Paper) [7414-26]

S. Residori, Institut Non Linéaire, CNRS, Univ. de Nice Sophia Antipolis (France); U. Bortolozzo, Univ. of Verona (Italy); J.-P. Huignard, Thales Research \& Technology (France)

7414 OS Rewritable Bragg holograms of azobenzene polymers with fast response (Invited Paper) [7414-27]

A. Shishido, H.-B. Cha, T. Ikeda, Tokyo Institute of Technology (Japan)

\section{POSTER SESSION}

7414 OV Low voltage adaptive $128 \times 128$ element liquid crystal micro lens array with electric tunable focal length [7414-31]

H. Li, K. Liu, X. Zhang, T. Zhang, X. Shen, Huazhong Univ. of Science and Technology (China)

7414 OY Electrochemiluminescence properties of nematic liquid crystal cells doped with rubrene [7414-34]

M. Honma, T. Horiuchi, M. Tanimoto, T. Nose, Akita Prefectural Univ. (Japan)

Author Index

iv 


\title{
Conference Committee
}

\author{
Symposium Chair
}

Zakya H. Kafafi, National Science Foundation (United States)

Conference Chair

Iam Choon Khoo, The Pennsylvania State University (United States)

Program Committee

Timothy J. Bunning, Air Force Research Laboratory (United States)

Shaw H. Chen, University of Rochester (United States)

Neil Collings, University of Cambridge (United Kingdom)

Jean-Pierre Huignard, Thales Research \& Technology (France)

Tomiki Ikeda, Tokyo Institute of Technology (Japan)

Francesco F. Simoni, Università Politecnica delle Marche (Italy)

David M. Walba, University of Colorado at Boulder (United States)

Session Chairs

$1 \quad$ Novel Liquid Crystalline Optical Materials

Iam Choon Khoo, The Pennsylvania State University (United States)

2 Liquid Crystal Lasers: Imaging and Tuning Devices

Kenneth L. Marshall, University of Rochester (United States)

3 Optical Tuning and Switching: Microwave Application

Kenneth L. Marshall, University of Rochester (United States)

4 Opto-optical Switching: Nonlinear Optics

Atsushi Shishido, Tokyo Institute of Technology (Japan)

5 Optical Switching, Optoelectronic Devices, Optical Manipulation Andy F.-G. Fuh, National Cheng Kung Univ. (Taiwan)

6 Wave Mixing, Slow Light, Holographic Devices, Nanomachine Iam Choon Khoo, The Pennsylvania State University (United States) 
Downloaded From: https://www.spiedigitallibrary.org/conference-proceedings-of-spie on 26 Apr 2023

Terms of Use: https://www.spiedigitallibrary.org/terms-of-use 